\title{
PENDIDIKAN KESEHATAN PADA IBU TENTANG GIZI KURANG PADA BALITA DI DESA SINDANGSARI KECAMATAN CIMERAK KABUPATEN PANGANDARAN
}

\author{
Syifa Agnia Nirmala*1, Dede Gantini ${ }^{1}$, Dita Eka Mardiani ${ }^{1}$ \\ 1 Jurusan Kebidanan Poltekkes Kemenkes Tasikmalaya, Indonesia \\ *e-mail: syifaagnianirmala@gmail.com
}

\begin{abstract}
Hunger and malnutrition cause the highest death rates worldwide. At least 17,289 children die every day due to hunger and malnutrition. Data from 496 districts / cities, as many as 404 districts / cities have acute-chronic nutritional problems, 20 districts / cities have chronic nutritional problems, 63 districts / cities have acute nutritional problems and 9 districts / cities that are not found nutritional problems. The purpose of this activity is to increase the knowledge of mothers about malnutrition in children under five in Sindangsari Village, Cimerak District, Pangandaran Regency through health education. The method used is health education. The subjects who participated in the activity were 9 mothers of children under five. To identify the knowledge of mothers under five, before and after health education, pre-test and post test were conducted. Based on the results of the assessment, it can be seen that the knowledge of mothers about malnutrition in children under five in Sindangsari Village about before health education was implemented most of them had less knowledge (66.7\%). After the implementation of health education, most of them have good knowledge (77.77\%). Meanwhile, the average value before health education (60.5\%) and after health education (88\%) was carried out. This represents an increase in knowledge of $27.5 \%$.
\end{abstract}

Keywords: Health Education, Maternal Knowledge, Undernutrition in Toddlers

\begin{abstract}
ABSTRAK
Kelaparan dan gizi kurang menyebabkan angka kematian tertinggi di seluruh dunia. Sedikitnya 17.289 anak-anak meninggal setiap hari karena sebab kelaparan dan gizi kurang. Data dari 496 Kabupaten/Kota, sebanyak 404 Kabupaten/Kota mempunyai permasalahan gizi yang bersifat AkutKronis, 20 Kabupaten/Kota mempunyai permasalahan gizi yang bersifat Kronis, 63 Kabupaten/Kota mempunyai permasalahan gizi yang bersifat Akut dan 9 Kabupaten/Kota yang tidak ditemukan masalah gizi. Tujuan dari kegiatan ini meningkatkan pengetahuan ibu tentang gizi kurang pada balita di Desa Sindangsari Kecamatan Cimerak Kabupaten Pangandaran melalui pendidikan kesehatan. Metode yang digunakan adalah metode pendidikan kesehatan. Subjek yang mengikuti kegiatan sebanyak 9 ibu balita. Untuk mengidentifikasi pengetahuan ibu balita, sebelum dan sesudah pendidikan kesehatan dilakukan pre-test dan post test. Berdasarkan hasil penilaian dapat diketahui pengetahuan Ibu tentang gizi kurang pada balita di Desa Sindangsari tentang sebelum dilaksanakan pendidikan kesehatan sebagian besar mempunyai pengetahuan kurang $(66,7$
\end{abstract}

61 Edukasi Masyarakat Sehat Sejahtera (EMaSS) : Jurnal Pengabdian kepada Masyarakat Volume 2 No.1 Tahun 2020 
$\%)$. Sesudah dilaksanakan pendidikan kesehatan sebagian besar mempunyai pengetahuan baik $(77,77 \%)$. Adapun rata-rata nilai sebelum dilakukan pendidikan kesehatan $(60,5 \%)$ dan sesudah dilakukan pendidikan kesehatan (88 \%). Ini menunjukkan peningkatan pengetahuan sebesar 27,5 $\%$.

Kata Kunci : Pendidikan Kesehatan, Pengetahuan Ibu, Gizi Kurang pada Balita

\section{PENDAHULUAN}

Gizi (nutrition) adalah suatu proses organisme menggunakan makanan yang dikonsumsi secara normal melalui proses digesti, absorpsi, transportasi, penyimpan, metabolisme dan pengeluaran zat-zat yang tidak digunakan untuk mempertahankan kehidupan, pertumbuhan dan fungsi normal organ-organ serta menghasilkan energi (Supariasa, 2017). Malnutrisi adalah keadaan patologis akibat kekurangan atau kelebihan secara relatif maupun absolut satu atau lebih zat gizi (Supariasa, 2013). Menurut tabel baku WHO-NCHS, Gizi kurang adalah keadaan zat gizi tingkat sedang yang disebabkan oleh rendahnya asupan energi dan protein dalam waktu cukup lama yang ditandai dengan berat badan menurut unur $(\mathrm{BB} / \mathrm{U})$ yang beradapada<-2 SD sampai $>-3$ SD.Anak dibawah lima tahun atau sering disebut Balita adalah anak yang telah menginjak usia diatas satu tahun atau lebih populer dengan pengertian usia anak dibawah lima tahun (Muaris H, 2006). Para ahli menggolongkan usia balita sebagai tahapan perkembangan anak yang cukup rentan terhadap berbagai serangan penyakit yang disebabkan oleh kekurangan atau kelebihan asupan nutrisi jenis tertentu (Kemenkes RI, 2015).

Masa balita merupakan periode penting dalam proses tumbuh kembang manusia perkembangan dan pertumbuhan dimasa itu menjadi penentu keberhasilan pertumbuhan dan perkembangan anak diperiode selanjutnya. Masa tumbuh kembang diusia ini merupakan masa yang berlangsung cepat dan tidak pernah terulang, karena itu sering disebut goldenage atau masa keemasan (Uripi,2004).Gizi adalah asupan makanan yang sesuai dengan kebutuhan diet tubuh. Gizi baik adalah keseimbangan antara asupan makanan dan aktivitas fisik. Kurang gizi dapat menyebabkan kekebalan tubuh berkurang, peningkatan kerentanan terhadap penyakit, gangguan perkembangan fisik dan mental serta mengurangi produktifitas (WHO, 2013). Status gizi (nutrion status ) adalah ekspresi dan keadaan keseimbangan dalam variabel tertentu. Sedangkan pengertian dari malnutrisi adalah keadaan patologis akibat kekurangan atau kelebihan secara relatif maupun absolut satu atau lebih zat gizi (Supariasa, 2013).

62 Edukasi Masyarakat Sehat Sejahtera (EMaSS) : Jurnal Pengabdian kepada Masyarakat Volume 2 No.1 Tahun 2020 
Berdasarkan data di Kabupaten Pangandaran periode (Januari - Desember) tahun 2019 jumlah balita sebanyak 27.487 yang tersebar di 15 Kecamatan, 663 diantaranya mengalami gizi kurang. Distribusi jumlah balita gizi kurang diantaranya Kecamatan Parigi terdapat 55 balita, Kecamatan Selasari 39 balita, Kecamatan Cijulang 23 balita, Kecamatan Cimerak 26 balita, Kecamatan Legokjawa 35 balita, Kecamatan Cigugur 21 balita, Kecamatan Langkaplancar 16 balita, Kecamatan Jadikarya 2 balita, Kecamatan Mangunjaya 5 balita, Kecamatan Padaherang 44 balita, Kecamatan Sindangwangi 68 balita, Kecamatan Kalipucang 151 balita, Kecamatan Pangandaran 55 balita, Kecamatan Sidamulih 42 balita, Kecamatan Cikembulan 11 balita.

\section{METODE}

Metode pengambilan kasus yang digunakan adalah metode pendidikan kesehatan. Pendidikan kesehatan ini dilakukan di Desa Sindangsari Kecamatan Cimerak Kabupaten Pangandaran. Waktu untuk memberikan pendidikan kesehatan pada ibu tentang gizi kurang pada balita ini di laksanakan 2 kali pertemuan mulai dari 24 Februari sampai 25 Februari 2020 dengan subjek yang terlibat dalam pemberian pendidikan kesehatan pada ibu tentang gizi kurang pada balita ini adalah ibu dengan balita yang beralokasi di Desa Sindangsari Kecamatan Cimerak Kabupaten Pangandaran. Sasaran ibu yang memiliki balita dengan gizi kurang adalah 9 orang. Proses pengumpulan data menggunakan kuesioner kepada ibu untuk mengevaluasi pengetahuan ibu setelah dilaksanakannya kegiatan pemberian materi pendidikan kesehatan. Sedangkan Instrumen pengumpulan data dalam kegiatan pendidikan kesehatan ini terdiri dari: SAP, Leaflet dan kuesioner untuk mengukur pengetahuan ibu tentang Gizi kurang pada balita yang berjumlah 15 soal dengan jenis jawaban pilihan ganda.

\section{HASIL DAN PEMBAHASAN}

Sebelum dilakukan pendidikan kesehatan dilakukan terlebih dahulu pengkajian pengetahuan ibu tentan gizi kurang pada balita dengan melakukan pengisian Pre - Test. Setelah dilaksanakan kegiatan pendidikan kesehatan pada ibu tentang gizi kurang pada balita maka diperoleh hasil sebagai berikut:

63 Edukasi Masyarakat Sehat Sejahtera (EMaSS) : Jurnal Pengabdian kepada Masyarakat Volume 2 No.1 Tahun 2020 
Tabel 1. Distribusi frekuensi pengetahuan ibu tentang gizi kurang pada balita di Desa Sindangsari Kecamatan Cimerak

\begin{tabular}{ccccc}
\hline \multirow{2}{*}{ Pengetahuan } & \multicolumn{2}{c}{ Sebelum Penyuluhan } & \multicolumn{2}{c}{ Sesudah Penyuluhan } \\
\cline { 2 - 5 } & Frekuensi & Presentase & Frekuensi & resentase \\
\hline Baik & 0 & & 7 & $77,77 \%$ \\
\hline Cukup & 3 & $33,33 \%$ & 2 & $22,22 \%$ \\
\hline Kurang & 6 & $66,67 \%$ & 0 & \\
\hline Rata-rata & \multicolumn{2}{c}{$60,5 \%$} & \multicolumn{2}{c}{$88 \%$} \\
\hline
\end{tabular}

Berdasarkan tabel 1 diatas dapat diketahui pengetahuan ibu tentang gizi kurang pada balita di Wilayah Kecamatan Cimerak sebelum dilakukan pendidikan kesehatan sebagian besar mempunyai pengetahuan kurang $(66,67 \%)$ sesudah dilaksanakan penyuluhan sebagian besar mempunyai pengetahuan baik $(77,77 \%)$. Dapat diketahuirata-rata nilai sebelum dilakukan pendidikan kesehatan $(60,5 \%)$ dan sesudah dilakukan penyuluhan $(88 \%)$ terjadi kenaikan $(27,5 \%)$.

Menurut Notoatmodjo (2010) Pengetahuan adalah hasil dari tahu setelah melakukan penginderaan terhadap suatu objek tertentu. Seseorang yang memiliki pengetahuan tinggi, maka ia akan mampu berfikir kritis. Seseorang yang memiliki pengetahuan tinggi tidak menjamin akan memiliki sikap dan perilaku yang positif. Karena dalam menentukan sikap selain ditentukan oleh pengethuan juka diperoleh oleh pikiran, keyakinan dan emosi yang memegang peran penting (Notoatmodjo, 2010).

Gizi kurang merupakan suatu keadaan dimana kebutuhan nutrisi pada tubuh tidak terpenuhi dalam jangka waktu tertentu sehingga tubuh akan memecah cadangan makanan yang berada dibawah lapisan lemak dan lapisan organ tubuh (Adiningsih, 2010).

Balita dikategorikan mengalami gizi kurang apabila berat badannya berada pada rentang Zscore $\geq-2.0 \mathrm{~s} / \mathrm{d}$ Zscore $\leq-3.0$ (Nasution, 2012). Anak dengan status gizi kurang ditandai dengan tidak adanya kenaikan berat badan setiap bulannya atau mengalami penurunan berat badan sebanyak dua kali selama enam bulan. Penurunan berat badan yang terjadi berkisar antara $20-30 \%$ dibawah berat badan ideal. Gizi kurang dapat berkembang menjadi gizi buruk, yaitu keadaan kurang gizi yang berlangsung lama sehingga pemecahan cadangan lemak berlangsung terus menerus dan dampaknya terhadap kesehatan anak akan menjadi semakin kompleks, terlebih lagi status gizi yang buruk dapat menyebabkan kematian (Adiningsih, 2010).

64 | Edukasi Masyarakat Sehat Sejahtera (EMaSS) : Jurnal Pengabdian kepada Masyarakat Volume 2 No.1 Tahun 2020 


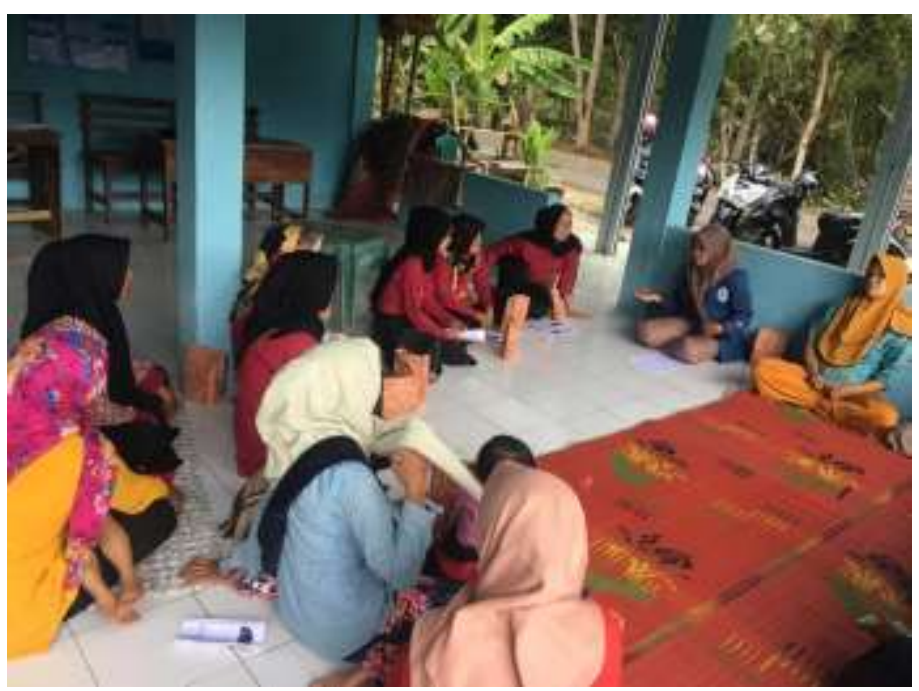

Gambar 1. Pemberian Pendidikan Kesehatan pada Ibu Balita

Kegiatan Pendidikan kesehatan ini telah dilakukan di Desa Sindangsari Kecamatan Cimerak Kabupaten Pangandaran tahun 2020 dengan responden ibu yang memiliki balita dengan gizi kurang berjumlah 9 orang.

Pada kegiatan ini penulis melakukan upaya untuk meningkatkan pengetahuan ibu tentang gizi kurang pada balita melalui pendidikan kesehatan. Pendidikan kesehatan adalah aplikasi atau penerapan pendidikan dalam bidang kesehatan. Secara operasional pendidikan kesehatan adalah semua kegiatan untuk memberikan dan peningkatan pengetahuan, sikap, praktek baik individu, kelompok atau masyarakat dalam memelihara dan meningkatkan kesehatan mereka sendiri (Notoatmodjo, 2012).

Pada tahap persiapan penulis melakukan koordinasi dengan pihak setempat terutama kepala dusun dan bidan desa di Desa Sindangsari Kecamatan Cimerak, menyampaikan maksud dan tujuan dilakukannya pendidikan kesehatan di Desa Sindangsari, menyiapkan bahan/materi untuk pendidikan kesehatan dengan menggunakan panduan SAP (Satuan Acara Penyuluhan) dan media leaflet.

Sebelum dilakukan pendidikan kesehatan dilakukan terlebih dahulu pengkajian pengetahuan ibu mengenai gizi kurang pada balita dengan melakukan pengisian soal Pre-test.Responden belum mengerti ataupun belum mengetahui bagaimana cara mereka mengatur kebutuhan gizi sehari-hari anaknya. Untuk itu penulis memberikan penyuluhan atau informasi yang berkaitan dengan gizi pada balita dengan menggunakan panduan SAP dan media leaflet. 
Leaflet adalah selembaran kertas yang berisi tulisan dengan kalimat-kalimat yang singkat, padat, mudah dimengerti dan gambar-gambar sederhana. Leaflet digunaka untuk memberikan keterangan singkat tentang suatu masalah (Notoatmodjo, 2010). Lealflet memiliki keunggulan, diantaranya menggunakan bahasa yang singkat dan jelas sehingga mudah dipahami isinya, di desain secara sistematis dengan ilustrasi sehingga menarik perhatian pembacanya dan bentuknya yang kecil sehingga mudah dibawa kemana-mana. Selain membuat leaflet penulis juga membuat SAP (Satuan Acara Penyuluhan) sebagai bahan/materi untuk pendidikan kesehatan. SAP (Satuan Acara Penyuluhan) adalah seperangkat acara penyuluhan yang akan diselanggarakan termasuk topik, tempat, sasaran, pemateri dan konsep acara.

Pada tahap pelaksanaan, metode yang digunakan ceramah dan tanya jawab. Metode ceramah adalah metode memberikan uraian atau penjelasan kepada sejumlah orang pada waktu dan tempat tertentu. Metode ceramah ini hanya mengandalkan indera pendengaran sebagai alat belajar yang paling dominan. Ceramah memiliki beberapa keunggulan diantaranya, praktis dari sisi persiapan, efisiens dari segi waktu dan biaya, dapat menyampaikan materi yang banyak dan lebih mudah mengontrol kelas.

Sedangkan tanya jawab menurut Rief (2010), metode tanya jawab adalah suatu teknik menyampaian pelajaran dengan cara guru mengajukan pertanyaan. Atau suatu metode di dalam pendidikan dimana guru bertanya sedangkan siswa menjawab tentang materi yang diperoleh. Tanya jawab memiliki beberapa keunggulan, diantaranya kelas akan lebih hidup karena partisipasi siswa lebih aktif dan berusaha mendengarkan pertanyaan yang diberikan guru dengan baik dan mencoba untuk memberikan jawaban yang tepat sehingga siswa akan menerima pelajaran dengan aktif berpikir, tidak pasif hanya mendengarkan saja

Setelah melakukan pendidikan kesehatan selama dua kali pertemuan, penulis melakukan evaluasi dengan menelaah tingkat pengetahuan responden dari hasil pre-test dan post-test. Berdasarkan hasil pre-test dan post-test terdapat peningkatan pengetahuan responden sebelum dilaksanakan pendidikan kesehatan sampai sesudah dilaksanakan pendidikan kesehatan. Sebelum dilakukan pendidikan kesehatan sebagian besar mempunyai pengetahuan kurang $(66,67 \%)$ sesudah dilaksanakan penyuluhan sebagian besar mempunyai pengetahuan baik (77,77 \%). Dapat diketahuirata-rata nilai sebelum dilakukan pendidikan kesehatan $(60,5 \%)$ dan nilai rata-rata sesudah dilakukan pendidikan kesehatan $(88 \%)$ dapat dilihat bahwa terjadi peningkatan pengetahuan $(27,5 \%)$. Hal ini menunjukan pendidikan kesehatan menjadi penyebab meningkatnya pengetahuan Ibu tentang gzi kurang pada balita di Desa Sindangsari Kecamatan Cimerak Kaabupaten Pangandaran.

66 | Edukasi Masyarakat Sehat Sejahtera (EMaSS) : Jurnal Pengabdian kepada Masyarakat Volume 2 No.1 Tahun 2020 
Menurut Notoatmodjo (2012) faktor yang mempengaruhi peningkatan pengetahuan seseorang adalah informasi dan pengalaman. Seseorang yang memiliki keluasan informasi akan semakin memiliki pengetahuan yang lebih luas. Pengalaman berkaitan dengan umur dan pendidikan individu, pendidikan yang tinggi pengalamannya akan luas sedangkan umur semakin banyak maka pengalaman juga semakin banyak. Sehingga setelah diberikan informasi melalui penyuluhan, pengetahuan dan sikap ibu terjadi peningkatan. Seiring bertambahnya ilmu pengetahuan, ibu akan lebih berpengalaman dalam pemberian gizi yang baik dan benar setelah diberikannya informasi.

\section{SIMPULAN}

Kesimpulan dari kegiatan pengabdian masyarakat yang telah dilakukan dapat diuraikan secara rinci dalam dua poin berikut :

a. Berdasarkan pelaksanaan kegiatan yang telah dilakukan, dapat disimpulkan bahwa pengetahuan yang benar dan tepat tentang Gizi Kurang merupakan salah satu poin penting dalam rangka mencegah kejadian stunting. Kegiatan ini berhasil meningkatkan pengetahuan ibu secara signifikan, hal ini juga dipengaruhi oleh penyuluh, ketertiban dan rasa ingin tahu sasaran dan proses pelaksanaan.

b. Pendidikan kesehatan ini juga diharapkan bukan hanya berpengaruh pada peningkatan pengetahuan ibu saja, tetapi mampu merubah perilaku dan menjadikan perilaku bertanggungjawab pada asupan nutrisi pada bayi/balita terutama untuk mencegah kejadian stunting. Diharapkan kedepannya akan terus dilakukan kegiatan serupa khususnya untuk ibu hamil sehingga bukan hanya pengetahuannya saja yang meningkat tetapi perubahan perilakunya juga dapat diawasi secara berkesinambungan guna meningkatkan pengetahuan ibu mengenai Gizi Kurang sehingga menjadi salah satu bentuk penanggulangan dan pencegahan stunting yang komprehensif mulai dari masa prenatal.

\section{DAFTAR PUSTAKA}

Adiningsih, S. (2010). Waspada Gizi Balita Anda. Jakarta : PT. Elex Media. Komputindo Apriana. (2012). Pengantar Gizi pada Balita. Jakarta : Kencana Prenada Media Marimbi.( 2010). Permasalahan Gizi Pada Blita. Yogyakarta : Graha Ilmu. Notoatmodjo, S. (2012). Pendidikan Kesehatan. Jakarta : Rineka Cipta. Notoatmodjo, S. (2010). Metodologi Penelitian Kesehatan. Jakarta :Rineka Cipta.

67 | Edukasi Masyarakat Sehat Sejahtera (EMaSS) : Jurnal Pengabdian kepada Masyarakat Volume 2 No.1 Tahun 2020 
Sugiyono. (2013). Metode penelitian pendidikan pendekatan kuantitatif, kualitatif, dan R\%D. Bandung: Alfabeta

Kementerian Kesehatan Republik Indonesia. Profil Kesehatan Indonesia. 2015. Tersedia dalam https://www.kemkes.go.id/resources/download/pusdatin/profil-kesehatan-indonesia/profilkesehatan-Indonesia-2015.pdf

Mansur, H \& Budiarti, T. (2014). Psikologi Ibu dan Anak Untuk Kebidanan. Jakarta: Salemba

Dinkes Kabupaten Pangandaran. Data jumlah balita dengan gizi kurang di Kabupaten Pangandaran tahum 2019.

Kemenkes RI.( 2013). Keputusan Menteri Kesehatan Republik Indonesia, No. K1995/KEMENKES/SK/XIV 2013 tentang penggolongan gizi menurut IndeksAntropometri Penilaian Status Gizi.

Kemenkes RI. (2013). Keputusan Menteri Kesehatan Republik Indonesia, No. 1995/KEMENKES/SK/XIV 2013 tentang Stantar Antropometri Penilaian Status Gizi.

Uripi. 2004. Menu Sehat Untuk Balita. Jakarta : Puspa Swara 